\title{
Literackie świadectwo (nad)wrażliwej pamięci Kilka uwag o Łodzi bukowej Janiny Kościałkowskiej
}

\section{The Literary Testimony of an (Over)sensitive Memory: On Janina Kościałkowska's Łódź Bukowa}

Abstract: The topic of the article is the nature of memory and remembrance in the work of Janina Kościałkowska, a literary artist associated with the Second Emigration, winner of Wiadomości award, and author of stories, plays, and novels. The topics under discussion in this paper are closely connected with the concepts of homeland, locality, and identity. Revisiting the past primarily speaks to the need for self-determination. These issues constitute an important element in Kościałkowska's works, and embody various forms of literary interpretation while attempting to come to terms with the history and canonical perception of emigration.

Key words: memory, emigration, local patriotism, biography, identity

Streszczenie: Tematem tekstu jest istota pamięci i pamiętania w twórczości Janiny Kościałkowskiej - autorki opowiadań, dramatów i powieści, laureatki nagrody „Wiadomości”, twórczyni związanej z Drugą Emigracją Niepodległościową. Omawiane zagadnienia są ściśle związane z pojęciami ojczyzny, małej ojczyzny i tożsamości. Powroty do przeszłości to przede wszystkim potrzeba samostanowienia. Kwestie te są ważnym elementem jej twórczości, przybierają różne formy interpretacji literackiej, a także są próbą "rozprawienia się” z historią i kanonicznym postrzeganiem emigracji.

Słowa kluczowe: pamięć, emigracja, mała ojczyzna, biografia, tożsamość 
Walter Benjamin pisze, że „pamięć jest przede wszystkim zdolnością epicką" ${ }^{\prime \prime}$ Myśl ta może stać się punktem wyjścia do próby omówienia jednego z tematów podjętych w twórczości Janiny Kościałkowskiej i obecnego w szczególny sposób w Łodzi bukowej². Problematyka zaprezentowana przez autorkę - przedstawicielkę Drugiej Emigracji Niepodległościowej - w omawianym utworze ma swoje źródło w doświadczeniu emigracyjnym. Stanowi mozaikę wątków (auto)biograficznych i tożsamościowych, a ich spoiwem jest potrzeba skomentowania oraz rozliczenia się z przeszłością i teraźniejszością, w której przyszło jej żyć i tworzyć. Do tych literackich prób prawdopodobnie skłoniła pisarkę wiara w siłę pamięci, która w niniejszym przypadku wydaje się dominująca i niemożliwa do opanowania, pamięci wręcz chimerycznej i "nachalnej”. W odniesieniu do Łodzi bukowej bez watpienia sprawdza się przekonanie Juliusza Kleinera, że pamięć jest integralnym składnikiem rzeczywistości przedstawionej utworów literackich ${ }^{3}$.

Podejmując rozważania o utrwalonych w słowie wyobrażeniach doświadczenia emigracji i związanym $\mathrm{z}$ nią przeżyciem utraty ojczyzny ze szczególnym uwzględnieniem procesu pamięci i pamiętania, warto wspomnieć o tym, że tematyka ta w sposób wyjątkowy była wyzyskiwana przez pisarki-emigrantki z wykorzystaniem różnorodnych strategii. Bożena Karwowska zauważa, że autorki te funkcjonują na obrzeżach kanonu polskiej literatury na obczyźnie, który reprezentują dzieła pisarzy uznanych za wybitnych, skoncentrowanych na działalności publicznej. $\mathrm{W}$ przeciwieństwie do nich bohaterki narracji kobiecych, niejednokrotnie porte-parole autorek, przebywają przede wszystkim w przestrzeni prywatnej, domowej. Inaczej też doświadczają wygnania: wydaje się, że kobietom łatwiej niż mężczyznom przychodzi pogodzić się z trudnymi warunkami życia na emigracji. Codzienność emigrantek zwykle ogranicza się do przestrzeni domu, narzucającej rolę żony i matki: „Pokrzyżowane plany, niespełnione ambicje, zakłócone przestrzenie - domowa i społeczna - $\mathrm{i}$ »przestarzała « tożsamość, a przede wszystkim bolesna samotność - to bilans po/wojennej kobiecej narracji wygnańczej”"t.

${ }^{1}$ W. Benjamin: Narrator. Rozważania o twórczości Mikołaja Leskowa. Przeł. K. Krzemieniowa. W: W. Benjamin: Anioł Historii. Eseje, szkice, fragmenty. Wybór i oprac. H. OrŁowski. Poznań 1996, s. 256.

2 J. KościaŁкоwsкa: Łódź bukowa. Londyn 1988.

3 J. KLeINeR: Rola pamięci w recepcji dzieła literackiego i jego strukturze. W: IDEM: Studia z zakresu teorii literatury. Lublin 1961, s. 79.

${ }^{4}$ B. Karwowska: Baśka, Barbara, Barbarita. Wygnanie w powojennej emigracyjnej prozie kobiecej. „Teksty Drugie” 2008, nr 3, s. 87. 
Takie ujęcia znajdujemy m.in. w prozie pisarek: Danuty Mostwin czy Janiny Surynowej-Wyczółkowskiej. Centralne motywy ich twórczości stanowią dom i rodzina. Dzieje się tak prawdopodobnie dlatego, że - jak podkreśla Karwowska - postawione we wspomnianej sytuacji kobiety czują się odpowiedzialne za „stworzenie domu i utrzymanie polskości następnego pokolenia" ${ }^{\prime \prime}$, a dzięki nim prywatne przestrzenie emigrantów stają się ośrodkami pamięci o kraju. W twórczości autorki Łodzi bukowej o domu i atmosferze z nim związanej mowa przede wszystkim w kontekście utraconej ojczyzny. Z kolei na emigracji dominującym poczuciem było dla niej „niezakotwiczenie”, które - jak wolno przypuszczać - nie mogło stać się podstawą stworzenia jakiegokolwiek miejsca w pełni oswojonego. Formą otaczania szacunkiem pamięci o Polsce i kultywowania wartości z nią związanych było np. pisanie bajek i działalność teatralna, o których wspominam w dalszej części szkicu.

Biografię Janiny Kościałkowskiej naznaczył bieg wydarzeń historycznych, który nie tylko wymusił na niej ważne decyzje życiowe, ale także ukształtował ją jako człowieka i pisarkę. Doświadczenia te funkcjonują $\mathrm{w}$ jej utworach na zasadzie autobiografizmu immanentnego, o którym pisała Maria Marcjan, rozumianego jako uobecnienie wątków osobistych nie tyle w pojedynczym utworze danego twórcy, ile raczej widocznych po zapoznaniu się z całokształtem jego dorobku'.

Biografia często stanowi klucz do interpretacji twórczości wielu pisarzy emigracyjnych i wyznacza zasadny punkt wyjścia rozważań na jej temat, dlatego warto wskazać najważniejsze zwroty w życiorysie Kościałkowskiej, ponieważ staną się one odniesieniem w odczytywanych w tym szkicu projekcjach pamięci. W studiach nad literaturą emigracyjną inspiracje biograficzne zazwyczaj pogłębiają znaczenia zawarte $\mathrm{w}$ analizach $\mathrm{i}$ bez wątpienia warto po nie sięgać. Rzecz jasna, z jednoznacznym zastrzeżeniem, że każdy utwór odzwierciedla fikcyjną rzeczywistość i zawsze możemy mieć do czynienia jedynie z artystycznym przetworzeniem osobistych doświadczeń autora, które od świata przedstawionego jego spuścizny trzeba w sposób wyraźny oddzielić.

Dzieciństwo Janiny Kościałkowskiej związane było ze Lwowem, w którym urodziła się 27 marca 1915 roku. Pochodziła z rodziny in-

\footnotetext{
${ }^{5}$ Ibidem, s. 79.

${ }^{6}$ M. Marcjan: Autobiograficzna strategia Tadeusza Brezy w świetle genologicznej struktury "Spiżowej bramy”. W: Biografia - geografia - kultura literacka. Red. J. ZıoMEK, J. SŁAwiŃski. Wrocław 1975, s. 123.
} 
teligenckiej. Była córką Marii z Szeligowskich i Jana Węgrzyńskiego. Jej matka zajmowała się prowadzeniem domu, ojciec pracował jako adwokat, pełnił także funkcję dyrektora banku. Rozpoczynając naukę, przyszła twórczyni przeniosła się do Jasła, w którym realizowała program nauczania z zakresu szkoły podstawowej pod czujnym okiem babki - Olgi Węgrzyńskiej.

Następnie została uczennicą Gimnazjum Żeńskiego im. bł. Jolanty w Jaśle, które ukończyła w 1933 roku. Atmosferę tamtych lat zapisała w pamięci głównie jako czas spokoju i radości. Kolejnym etapem jej kształcenia, który jednocześnie sprawił, że powróciła do miasta swego urodzenia, były studia na wydziale malarskim i tekstylnym Państwowego Instytutu Sztuk Plastycznych we Lwowie. Zakończenie formalnej edukacji przyszłej pisarki przypadło na lipiec 1939 roku. Wydaje się, że były to ostatnie beztroskie wakacje w jej życiu.

Wybuch II wojny światowej wymusił na Kościałkowskiej decyzje, których z pewnością wcześniej nie dało się przewidzieć, podjęte ze względu na ówczesną sytuację polityczną. Konsekwencją rozstrzygnięć historii był nowy rozdział w jej życiu - emigracyjny szlak. Świadoma wojennej grozy, niezależnie od posiadanego wykształcenia, podała się za robotnicę i zatrudniła $w$ jednej z lwowskich fabryk włókienniczych. Wkrótce po tym otrzymała wezwanie do pracy w redakcji "Czerwonego Sztandaru”, które postanowiła zignorować. Świadoma jednak represji - ciążyło nad nią widmo deportacji ukrywała się we Lwowie.

Kolejnym etapem na jej wygnańczej ścieżce była przymusowa praca $\mathrm{w}$ Weimarze - w drukarni Borkmana, w której zajmowała się projektowaniem reklam handlowych. Maj 1941 roku przyniósł pozytywne zmiany w jej życiu - po opuszczeniu Niemiec przedostała się do Szwajcarii. Tam zawarła związek małżeński ze Stanisławem Edwardem Nahlikiem, który pełnił funkcję sekretarza poselstwa Rzeczypospolitej w Bernie ${ }^{7}$. Status żony dyplomaty sprawił, że mogła poświęcić się pracy literackiej i społecznej, skupiającej się przede wszystkim na działalności związanej z teatrem. Podejmowane przez nią wyzwania (m.in. jako wiceprezesa Towarzystwa Polskiego) koncentrowały się na propagowaniu wiedzy o historii literatury polskiej i adresowane były do jej rodaków przebywających wówczas w Szwajcarii.

W 1945 roku rozstała się z mężem. W osobistym postanowieniu rozwodu niebagatelną rolę odegrał czynnik polityczny - Kościałkowska nie zaakceptowała decyzji małżonka o podporządkowaniu

7 Warto dodać, że pierwszy mąż pisarki również wydał swe pamiętniki, por. S. Nahlik: Przesiane przez pamięć. T. 1-3. Kraków 1987-2002. 
się ówczesnym władzom rządowym w Warszawie i powrocie do kraju. Kolejnym przystankiem na jej życiowej mapie stał się Londyn, w którym pracowała jako projektantka druków reklamowych i ceramiczka. W 1948 roku ponownie wyszła za mąż - za Wacława Zyndrama-Kościałkowskiego, z którym zamieszkała we francuskim mieście Laloubère u podnóża Pirenejów. Od tamtej pory jej życie zogniskowało się wokół pracy artystycznej - zarówno typowo literackiej, jak i związanej z rękodziełem, tj. z ręcznym malowaniem porcelany. $W$ nowym miejscu zamieszkania otworzyła pracownię dekoracyjną. Zmarła 23 lipca 2004 roku w Laloubère.

Janina Kościałkowska odwiedzała ojczyznę kilkakrotnie. Wizyty te wiazały się z jej aktywnością pisarską, która była jej szczególnie bliska. Pierwszy raz powróciła do powojennej Polski w 1969 roku. Kolejne pobyty skutkowały ważnymi wydarzeniami - po roku 1989 nawiązała kontakt z instytucjami krajowymi, m.in. z Archiwum Emigracji w Toruniu, w którym zdeponowany został jej dorobek. W 1991 roku została członkinią Związku Pisarzy Polskich na Obczyźnie. Z kolei w 1993 roku otrzymała tytuł Honorowego Obywatela Miasta Jasła. Wszystkie te daty wyznaczają jej powojenne podróże do ojczyzny.

Dorobek Janiny Kościałkowskiej obejmuje liczne utwory napisane w ciągu półwiecza, dlatego jej twórczość zostanie tutaj jedynie zwięźle naszkicowana, co nie może odbyć się bez uproszczeń. Warto wspomnieć ponadto, że jej spuścizna jest bardzo zróżnicowana pod względem gatunkowym.

Była autorką wielu opowiadań publikowanych głównie na łamach emigracyjnych periodyków - „Wiadomości”, „Ostatnich Wiadomości”, ,"Tygodnia Polskiego", „Dziennika Polskiego i Dziennika Żołnierza". Ich fabuła dotyczyła przede wszystkim okresu jej dzieciństwa i młodości - ludzi i miejsc zapamiętanych jeszcze z czasów jasielskich i lwowskich. Ponadto pisarka zabierała w nich głos na temat doświadczenia Zagłady, wspierając się przy tym swoimi przeżyciami z pobytu w hitlerowskich Niemczech.

Odrębną kategorię stanowią powieści, w które została włączona narracja kryminalna - Trzeci od prawej (1955), Sprawa numer jeden (1967) i Ostatni weekend w Paryżu (2001). Nie na tym jednak koniec, gdyż Kościałkowska wydała także zbiór poezji Poemat $z$ dyliżansem (1946) oraz trudny do jednoznacznego zaklasyfikowania genologicznego utwór, który można określić mianem żołnierskich zapisków, zatytułowany Kapliczka przydrożna (zapiski wrześniowe). Został on wydany w 1958 roku i nagrodzony pozakonkursową Nagrodą im. Kardynała Prymasa Polski Augusta Hlonda. 
Oddzielną grupę utworów stanowią zachowane w rękopisach, nieopublikowane do tej pory dramaty: Karczma Rzym, Arcypanna, Sen nocy letnich, Kwartet o zachodzie słońca, Sny prorocze ściętej głowy.

W utworach Kościałkowskiej zauważalna jest nie tylko próba utrwalania pamięci o czasach, w których żyła, ale także troska o przyszłe pokolenia i ich świadomość dotyczącą kraju pochodzenia rodziców. Świadectwem pielęgnowania tych wartości są napisane przez nią bajki: Historia o Krzysiu i jego zebrze oraz Bajka o stuku puku. Podobnie jak utwory dramatyczne, nie zostały one wydane ${ }^{8}$. W tekstach tych Kościałkowska, stosując atrakcyjne z perspektywy dziecka środki estetyczne, eksponuje wiarę $\mathrm{w}$ wartości narodowe i rodzimą tradycję. Kładzie szczególny nacisk na miłość do ojczystego języka i szacunek dla patriotycznych symboli.

Godną uwagi warstwą jej twórczości jest autobiografizm. Sygnalizują go m.in. bliskie pisarce przestrzenie i znaki topograficzne, a także zakorzenienie $\mathrm{w}$ tradycji literackiej charakterystycznej dla jej pokolenia i podejmowanie próby dystansowania się od niej. Emblematem rozpoznawczym autobiografizmu Kościałkowskiej jest także kreowanie wizji utraconej ojczyny i rzeczywistości emigracyjnej, utrwalonych $\mathrm{w}$ jej pamięci, a w jej spuściźnie literacko przetworzonych. Dorobek pisarki stanowi ważne uzupełnienie panoramy literatury emigracyjnej, ponieważ wzbogaca ją o oryginalne ujęcia figury emigranta, wizję małych ojczyzn jako miejsc utraconych (Jasła i Lwowa) oraz przestrzeni oswajanych (Londynu i Laloubère).

W artystycznym dorobku Janiny Kościałkowskiej Łódź bukowa zajmuje miejsce szczególne. Dzieje się tak przede wszystkim za sprawą wyjątkowej wrażliwości obecnej i wyczuwalnej w lekturze książki. Warto dodać, że ten walor utworu zadecydował o przyznaniu pisarce w 1989 roku nagrody „Wiadomości”. Łódź bukowa przynosi próbę opisania kondycji emigrantów niepodległościowych - zarówno w ujęciu indywidualnym, jak i zbiorowym. Ten etap swojego życia Kościałkowska skomentowała w sposób następujący:

W lecie 1945 roku opuściłam Szwajcarię i przyjechałam do Anglii. Zamieszkałam wtedy w Londynie, lecz właściwym miejscem mego pobytu $\mathrm{w}$ tym czasie wydaje mi się dziś cmentarz jasielski na Podkarpaciu, gdzie mieszkali ongiś, w tym bardzo małym mieście moi dziadkowie. Nie była to jednak z mojej strony wyprawa sentymentalnych wspomnień, wręcz przeciwnie 9 .

${ }^{8}$ Znajdują się one w Archiwum Emigracji w Toruniu.

9 J. Kоścıаєкошsка: Łódź bukowa..., s. 10. 
Obraz ten będzie często powracał w wizjach narratorki-bohaterki w Łodzi bukowej. Przestrzeń cmentarza zyskuje tutaj uniwersalny wymiar, staje się emblematem powinności wobec historii. Piotr Skórzyński w recenzji, której nadał znamienny tytuł Navigare necesse est, słusznie zauważa, że

klęska narodu wyzwoliła u bohaterki wspomnienia całkiem osobiste, poczucie winy - wobec mianowicie dawnych emigrantów, których kazano jej czcić i podziwiać, a o których ona miała ochotę jak najszybciej zapomnieć ${ }^{10}$.

W ten sposób w pamięci Kościałkowskiej uwidacznia się wyraźny spór z tradycją i historią ${ }^{11}$.

Pisząc o Łodzi bukowej, nie sposób pominąć kwestii tożsamości, która współistnieje z pamięcią. Należy również zastanowić się nad tym, czy w ogóle słuszne jest użycie określenia „emigrantka” w kontekście tego etapu biografii pisarki - jeśli uwzględnić jej punkt widzenia na ten temat. Do takich refleksji skłania choćby stwierdzenie:

Samo słowo "emigrant” miało w sobie coś żenującego, w przeciwieństwie do słowa „podróżnik”. Podróżnik to badacz i uczony, pan własnego wyboru i decyzji, emigrant zaś zalatywał od razu martyrologią oraz przymusem podziwiania przez późniejsze wnuki najsmutniejszych zdarzeń czy wręcz sytuacji. Ludzie szczęśliwi nie bywają emigrantami, dlaczegóż więc ryć na ich grobach, w marmurze, kamieniu czy granicie, nieraz zaś szczodrze złocić fakt, że byli to nieszczęśnicy? ${ }^{12}$

Namysł nad położeniem poprzedników Drugiej Emigracji Niepodległościowej inspiruje do rozważań dotyczących osobistej sytuacji emigrantki. W przypadku Kościałkowskiej wiedzie on do poszukiwania własnego „,ja", próby samookreślenia. Przybiera zarazem formę procesu zawieszonego i niedokończonego. Dla pisarki odkrywanie to rozgrywa się w cieniu historycznej i kulturowej przeszłości, w którą uwikłany jest przyjęty przez nią system wartości, silnie oddziałujący na obrazy, jakimi się posługuje. Dość przywołać choćby takie konstatacje:

10 P. Skórzyński: Navigare necesse est. „Nowe Książki” 1992, nr 12, s. 40.

${ }^{11}$ Por. E. Rүвіска: Miejsce, pamięć, literatura (w perspektywie geopoetyki). „Teksty Drugie" 2008, nr 1-2, s. 26.

12 J. KościaŁKowsKa: Łódź bukowa..., s. 10. 
Gniew dodawał sił, nawet bezsilny gniew ratuje ostatnie szczątki godności, która to "godność" poczynała być sama w sobie czymś śmiesznym, mocno żenującym, pretensją bez pokrycia. Na jej miejsce pojawiała się urągliwa bezosobowość, jakaś wewnętrzna gąbczastość - dziwaczna i odpychająca. Podobieństwo do gąbki upokarzało i denerwowało najbardziej. Za każdym razem pociśnięciem wypływają z takiego stworzenia (ongi żywego) cudze soki, obce i przypadkowe, porowatość i chłonność gąbki stanowi o jej użyteczności, a samo pojęcie użyteczności rozpływa się i mąci ${ }^{13}$.

To artystyczna rozprawa ze stereotypami i mitami, czego była z pewnością świadoma narratorka-bohaterka:

Mit nie rodzi się z biegiem czasu, lecz z uderzeniem pioruna. Pomiędzy wspomnienia prawdy prawdziwej, jeśli się ją traci zbyt nagle lub zbyt strasznie, wciska się mit, żeby nas jakoś podeprzeć. Mitotwórcze czujniki sięgały już po nas, na emigracji, choć byliśmy świadkami epoki. Szybko więc trzeba przypomnieć sobie widoki, słowa, historie ludzi, zanim powlecze ich apoteoza albo nicość ${ }^{4}$.

Z owych rozmyślań, powodowanych doświadczeniem wychodźstwa, wyrasta utwór Łódź bukowa. W tym kontekście nad wyraz słuszna wydaje się uwaga Mai Cybulskiej, odnotowana w odniesieniu do innego dzieła autorki - Bih $m e^{115}$, w swojej uniwersalności obejmująca jednak również znaczenia omawianego utworu:

Tekst wychodzi poza przygniatającą codzienność. Powieść, nie-powieść, pamiętnik, wyznanie, autobiografia, refleksje językowe, historie, obyczaj, trochę traktatu botanicznego - wszystko tam jest. O czymś się mówi, przerywa, wprowadza nowy wątek, który się rozgałęzia, umyka, powraca w innym układzie; coś jak echa, mgnienia, błyski, przybliżenia i oddalenia obrazów ${ }^{16}$.

Recepcja Łodzi bukowej skłania do podobnych wniosków. Wydaje się ponadto, że sposób konstruowania w niej rzeczywistości składa

${ }^{13}$ Ibidem, s. 17.

${ }^{14}$ Ibidem, s. 142

${ }^{15}$ J. KościaŁkowska: Bih me! Wstęp, oprac. i przypisy W. Lewandowski. Warszawa 2000.

16 M. Сүвulska: „Wyspy cudownych przeobrażeń”. „Kultura” [Paryż] 2000, nr 7/8, s. 208. 
się na autorską, oryginalną technikę pisarską Kościałkowskiej. Wypada dopowiedzieć, że jest to pełen paradoksów przykład dzieła jednocześnie heterogenicznego i spójnego, które uzupełnia XX-wieczną historię literatury emigracyjnej o nowe, kobiece spojrzenie. Wacław Lewandowski słusznie zauważa, że:

Łódź bukowa pisana jest językiem czystym i wielostrunowym, zanurzonym czasami w staropolszczyznę, ale jednocześnie niezmiernie świeżym. Już niewielu pisarzy pisze tak szczodrze. [...] [Janina Kościałkowska - E.D.] jest znakomitą pisarką i jej Łódź bukowa jest książką rzadkiej piękności ${ }^{17}$.

By jeszcze lepiej zrozumieć literacki charakter utworu, warto wspomnieć o kwestii jego przynależności gatunkowej. Wacław Lewandowski $\mathrm{w}$ swoich omówieniach słusznie proponuje uznać Łódź bukowa za quasi-pamiętnik i określa ją mianem "autoportretu" Drugiej Emigracji. Warto również rozważyć pomysł Tymona Terleckiego, który zobaczył w książce Kościałkowskiej speculum. Rozpoznanie to również wydaje się celne, ponieważ lektura utworu sprawia, że czytelnik odnosi wrażenie przenikania się elementów, o których mowa $\mathrm{w}$ definicji gatunku ${ }^{18}$, takich jak prezentacja wzorców osobowych czy wyrażanie wiary $\mathrm{w}$ istniejące normy moralne. $\mathrm{W}$ rezultacie w świecie przedstawionym teraźniejszość i przeszłość współistnieją, podobnie jak towarzyszące im wspomnienia i refleksje: „Tak więc, pisząc tę książkę, powracałam coraz bardziej w ten świat przeszły, który się rozrastał i utwierdzał, a wtedy, gdy był sobą, przelewał się miękko i wyboiście, nie krzepnął w nieodwołalności"19. Ze względu na synkretyczny charakter Łodzi bukowej arbitralne rozstrzygnięcie genologiczne nie jest możliwe.

Trudno także jednoznacznie wskazać głównych bohaterów utworu. Pojawiają się w nim postaci, w których można doszukać się kreacji osób, z jakimi pisarka miała kontakt, mieszkając w Londynie, a także zapamiętanych jeszcze z pobytu w Jaśle czy we Lwowie. Jest to ponadto literacka wizja rzeczywistości na poły fikcyjnej, na poły realnej, która została opisana językiem pełnym nawiązań, aluzji, kryptocytatów:

Najtrudniej było schronić się od strony przeszłości. Czułam, że jeżeli popadnę we wspomnienia, przepadnę. Należało pamiętać,

${ }^{17}$ W. Lewandowski: Wstęp. W: J. KościaŁkowska: Bih me!..., s. 16.

${ }^{18}$ Por. ibidem, s. 14.

19 J. KościaŁKowsKa: Łódź bukowa..., s. 203. 
można było sobie coś przypomnieć, lecz nie wspominać - i to subtelne, ale jakże absurdalne rozróżnienie stało się nakazem chwili, czymś jak jedyne lekarstwo na przetrwanie. Jeżeli zacznę drogę wstecz, ku temu co było, ucieknie ze mnie życie. Wspomnienia unieruchamiają, nadają byt wtóry, stan wyjątkowy, w którym poruszamy się z poczuciem jakichś gwarancji i pewności, kiedy w rzeczywistości nie umiemy się ustrzec od złudy. Trzeba się wystrzegać wspomnień, mówiłam sobie, bo natychmiast upodobnię się do starych emigrantów, którzy żyli tęsknotą i na nią umarli $\mathrm{w}$ co raptem uwierzyłam jak w rzecz dowiedzioną ${ }^{20}$.

Ważny w kontekście omawianych zagadnień jest również sam tytuł utworu, którego interpretacja stanowi swego rodzaju klucz do odczytania zawartych w nim sensów. Na poziomie intertekstualnym zawiera on odwołanie do Odprawy posłów greckich Jana Kochanowskiego i pojawiającego się w niej symbolu łodzi bukowej. Trop ten wskazuje sama autorka. Zaznacza jednak, że aluzja literacka nie polega wyłącznie na wykorzystaniu symbolu kulturowego w jego klasycznym rozumieniu. Tytułowe drzewo, chociaż kojarzone jest z długowiecznością i trwałością, nie daje poczucia stabilności. To raczej obraz stanu emigracyjnego moratorium:

A cóż łódź winna, że do nich chór się zwraca jak do sprawcy złego? Została zbudowana z najlepszego drewna, z buka, na górze Ida, skąd najwspanialsze maszty wybierano i najprzedniejsze budowano łodzie. Cóż była winna, że ją to właśnie obciążył ten łup przestępczy. [...] Zawsze zastanawiał mnie ten passus do łodzi. A to i nas wszakże wysadzano teraz u brzegów rzeki, aby nas "wychowała”, choć żaden ojciec nie chciał nas pozbawić życia, a tylko niektórych powinien był pędzić precz, tych, co „stokorodnej", czyli różnorakie zdroje rodzącej, za ojczyznę uznać nie chcieli. Nauczono nas mitologii i znaliśmy łacinę i przez to wyobrażaliśmy sobie, że należymy do Zachodu. I cóż? Mitologia już niejednego z nas śmieszyła, z tych, co przeżyli piekło wojny, lecz każdy zaczynać musi teraz od budowania sobie czegoś z czegoś bodaj jakiejś tratwy ${ }^{21}$.

Literackie nawiązanie do łodzi będzie powracało w utworze, by ostatecznie stać się jego podsumowaniem. Bohaterka, obserwując papierową łódkę kołyszącą się na rzece, tak to komentuje:

${ }^{20}$ Ibidem, s. 22.

${ }^{21}$ Ibidem, s. 210. 
Podjęłam tę zmiętą łódeczkę z papieru. Otrzepałam ją z wody; włożona między stulone palce nabierała podobieństwa do samej siebie sprzed katastrofy, gdy wyschnie, zachowam ją, napiszę na niej datę dnia dzisiejszego, będzie mi towarzyszyć w moich przyszłych odysejach. Towarzyszyła mi wiernie i długo ${ }^{22}$.

Stąd słuszna wydaje się uwaga Agnieszki Czachowskiej, która w artykule Ocalony stateczek pisze, że:

człowiekowi czującemu i wrażliwemu nic nie zostanie oszczędzone i przyjdzie taka chwila, że będzie potrzebował schronienia choćby w pozornie kruchej łupinie, która przeniesie go przez dziejową burzę. Musi tylko bardzo chcieć ją odnaleźć ${ }^{3}$.

Podróże w głąb wrażliwej pamięci nie są materializowane wyłącznie za pomocą słowa pisanego, przybierającego formę utworu literackiego. Istotne jest również miejsce, w którym odbywa się akt tworzenia. Co ciekawe, podczas pobytu $\mathrm{w}$ Londynie pisarka za drobną opłatą wynajęła małą, skromną łódkę, by na niej utrwalać projekcje wrażliwej pamięci i przemyślenia na temat teraźniejszości. Wybór ten nie był przypadkowy - miejsce to nastrajało ją melancholijnie. „,...] nie chciałam pisać mojej książki u siebie, aby się nie czuć zadomowiona" 24 - wspomina. Czyn twórczyni zyskuje uzasadnienie w stwierdzeniu Elżbiety Rybickiej, zauważającej, że „ścisły związek pomiędzy gestem pisarskim a materialnością miejsca dowodzi, iż miejsce i literatura potrzebują się wzajemnie"25.

W innym fragmencie pracy Czachowska przytacza następujące słowa Kościałkowskiej:

[...] nie szło wtedy o żaden pejzaż rzeczny ani olejny, ani akwarelę. Że pisałam tam pewne rzeczy, których nie chciałam pisać na lądzie. Na stałym lądzie [...]. Nie, to nie szło o żaden "temat marynistyczny". Tylko niezakotwiczenie. Nie chciałam czuć się osiedlona [...]. Woda jest bardziej... i tu zabrakło mi angielskiego wyrazu „spławna"26.

W omawianym utworze odnajdujemy ponadto powinowactwo na poziomie etymologicznym pojęć „pamięć” i „krajobraz”, które są

${ }^{22}$ Ibidem, s. 229.

23 A. Czachowska: Ocalony stateczek. „Twórczość” 1990, nr 9, s. 95.

${ }^{24}$ Ibidem, s. 82

25 Е. Rүвіска: Miejsce, pamięć, literatura..., s. 26.

26 A. Сzaсношsка: Ocalony stateczek..., s. 150. 
formą projekcji pamięci o rodzimej krainie. Krajobraz więc, jak pisze Denis Edward Cosgrove, ,jest sposobem postrzegania świata"27. Analizowany projekt mnemiczny poprzez odwołania do pejzażu przynosi rejestr pracy pamięci, który uchwyci jej nieopanowany rytm. Zauważalna jest świadomość przemijania, potrzeba pielęgnowania, zachowywania żywości dawnych czasów ze szczególnym uwzględnieniem budowania poczucia tożsamości:

Przywiązanie do krajobrazu było niebezpieczne, bardziej niż ludzie czy idee. Przywiązanie to, obsesyjne i intymne przebywanie z nim i obcowanie w literaturze (chyba rekord światowy przyrody i delektacji nią) cisnęło się gwałtownie i uparcie poprzez inne problemy, dyktowało częstokroć inne decyzje. Do tego stopnia, że trzeba się było uciekać do jakichś wybiegów, do szukania imitacji lub widoków najmniej sprzecznych z tymi, które egzaltowała pamięć i pozostanie ${ }^{28}$.

Powidoki zostały chociaż częściowo odzyskane przez fabułę literacką - to jednak proces ponownego konstruowania, nie zaś rekonstruowania. Analizując powyższy fragment, warto powołać się na uwagi Georga Simmla, który zauważa, że krajobraz jest swego rodzaju tworem duchowym, pozostającym w związku z całością natury, ale i sam jawi się człowiekowi jako summa wyłaniająca się z jego poszczególnych elementów w wyniku procesów duchowych ${ }^{29}$.

Podsumowując, można powiedzieć, że w twórczości Janiny Kościałkowskiej ojczyzna wywołuje przede wszystkim krąg znaczeń związanych z pamięcią i pamiętaniem, zespolonych z tożsamością i aktem autobiograficznym. Prowadzona w Łodzi bukowej narracja jest zapisem próby osiągnięcia $\mathrm{w}$ niej spójności przy równoczesnej świadomości rozdwojenia. Bohaterka-narratorka ulega procesom, o których pisze David Lowenthal, celnie dostrzegając, że:

każdy rodzaj pamięci modyfikuje i przekształca doświadczenie, raczej destyluje przeszłość, niż odzwierciedla ją bezpośrednio. Jesteśmy w stanie przywołać jedynie znikomy ułamek tego, co na nas w życiu oddziałuje, nie mówiąc już o wszystkich towarzyszących temu okolicznościach zewnętrznych. Pamięć zatem przesie-

${ }^{27}$ Cyt. za: B. Frydryczak: Od estetyki $i$ the picturesque do doświadczenia topograficznego. Poznań 2013, s. 47.

28 J. KościaŁкоwsкa: Łódź bukowa..., s. 100.

${ }^{29}$ Por. G. Simmel: Filozofia krajobrazu. W: Inem: Most i drzwi. Wybór esejów. Przeł. M. Łukasiewicz. Warszawa 2006, s. 294. 
wa raz jeszcze to, co już wcześniej odsiała percepcja i z pierwotnego oglądu zostawiła nam tylko fragmenty fragmentów, okruchy okruchów ${ }^{30}$.

Spostrzeżenia badacza w interesujący sposób dopełniają przedstawione wyżej rozważania na temat autobiografizmu Kościałkowskiej. Jak się okazuje, wszystko, na co zwraca uwagę pisarka (oraz każdy twórca i twórczyni w ogóle), jest rezultatem niepowtarzalnego spojrzenia na świat i przynosi pośrednią autocharakterystykę piszącego. Trzeba przyznać, że mimo ograniczoności ludzkiej pamięci i wynikającej z niej niedoskonałości poznania autorka Łodzi bukowej zdołała w niebanalny artystycznie sposób utrwalić obszerne fragmenty bliskiej jej rzeczywistości.

Konkludując, posłużmy się obserwacją Piotra Bratkowskiego, który pisze, że „narracja Kościałkowskiej jest silnie dygresyjna, chwilami pogmatwana jak myśli człowieka w rozterce" ${ }^{\prime 31}$. Właśnie takie jej ukształtowanie odzwierciedla szlaki, którymi podąża istota ludzka w swoim wewnętrznym świecie - częstokroć bezładnym, zdominowanym przez wielość bodźców. Patrząc z tej perspektywy, można powiedzieć, że narracja w Łodzi bukowej jest nad wyraz realistyczna, choć bez wattpienia pozostaje w opozycji względem nienaturalnej w swej doskonałości narracji typowej dla powieści realistycznej.

\section{Bibliografia}

Benjamin W.: Anioł Historii. Eseje, szkice, fragmenty. Wybór i oprac. H. Oreowski.

Przeł. K. Krzemieniowa. Poznań 1996.

Benjamin W.: Narrator. Rozważania o twórczości Mikołaja Leskowa. Przeł. K. Krze-

mieniowa. W: W. Benjamin: Anioł Historii. Eseje, szkice, fragmenty. Wybór i oprac. H. OrŁowski. Poznań 1996, s. 211-270.

Biografia - geografia - kultura literacka. Red. J. SŁAwiński. Wrocław 1975.

Bratkowski P.: Po co? Dlaczego? "Gazeta Wyborcza”, 1.04.2000, s. 12.

Cүвulska M.: „Wyspy cudownych przeobrażeń”. „Kultura” [Paryż] 2000, nr 7/8, s. 205-209.

Czachowska A.: Ocalony stateczek. „Twórczość” 1990, nr 9, s. 93-95.

Frydryczak B.: Od estetyki $i$ the picturesque do doświadczenia topograficznego. Poznań 2013.

KarwowsKa B.: Baśka, Barbara, Barbarita. Wygnanie w powojennej emigracyjnej prozie kobiecej. „Teksty Drugie” 2008, nr 3, s. 68-87.

${ }^{30}$ D. Lowenthal: Pamięć i zapomnienie. Tłum. I. GrudzińśKA-Gross, M. Tański. „Res Publica” 1991, nr 3, s. 16.

31 P. Bratkowski: Po co? Dlaczego? "Gazeta Wyborcza", 1.04.2000, s. 12. 
Kleiner J.: Rola pamięci w recepcji dzieła literackiego i jego strukturze. W: IDEm: Studia z zakresu teorii literatury. Lublin 1961, s. 71-83.

KLeINer J.: Studia z zakresu teorii literatury. Lublin 1961.

KościaŁkowska J.: Bih me! Wstęp, oprac. i przypisy W. Lewandowski. Warszawa 2000.

KościaŁkowska J.: Łódź bukowa. Londyn 1988.

Lewandowski W.: Wstęp. W: J. KościaŁkowska: Bih me! Wstęp, oprac. i przypisy W. LeWANDOWsKi. Warszawa 2000, s. 5-17.

Lowenthal D.: Pamięć i zapomnienie. Tłum. I. GrudzińśKa-Gross, M. Tański. „Res Publica" 1991, nr 3, s. 6-22.

Marcjan M.: Autobiograficzna strategia Tadeusza Brezy w świetle genologicznej struktury "Spiżowej bramy”. W: Biografia - geografia - kultura literacka. Red. J. Zıомeк, J. SŁawiński. Wrocław 1975, s. 119-137.

Nahlik S.: Przesiane przez pamięć. T. 1-3. Kraków 1987-2002.

Rүвіска E.: Miejsce, pamięć, literatura (w perspektywie geopoetyki). „Teksty Drugie” 2008, nr 1-2, s. 19-32.

Simmel G.: Filozofia krajobrazu. W: Inem: Most i drzwi. Wybór esejów. Przeł. M. ŁuKAsIEwicz. Warszawa 2006, s. 292-297.

Simmel G.: Most i drzwi. Wybór esejów. Przeł. M. Łukasiewicz. Warszawa 2006.

Skórzyński P.: Navigare necesse est. „Nowe Książki” 1992, nr 12, s. 40-41.

Erwina Dybisz - doktorantka literaturoznawstwa na Wydziale Filologicznym Uniwersytetu Rzeszowskiego. W 2017 roku obroniła pracę magisterską pt. Miasto marzeń i klęski. Obrazy Londynu w polskiej literaturze migracyjnej po 2000 roku. Obecnie przygotowuje rozprawę doktorską dotyczącą Janiny Kościałkowskiej.

e-mail: erwina.dybisz@gmail.com 